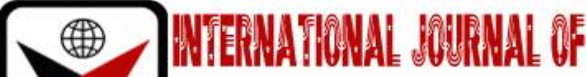

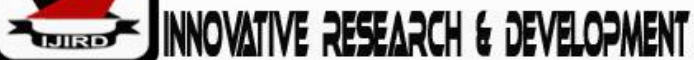

ISSN 2278-0211 (Online)

\section{Corporate Governance and Business Sustainability of Deposit Money Banks in Nigeria}

\author{
Hassan, A.T \\ Student, Department of Business Administration and Marketing, \\ Babcock University, Ilishan Remo, Ogun State, Nigeria \\ Owolabi, S.A \\ Lecturer, Department of Accounting, \\ Babcock University, Ilishan Remo, Ogun State, Nigeria \\ Asikhia, 0.U \\ Lecturer, Department of Business Administration and Marketing, \\ Babcock University, Ilishan Remo, Ogun State, Nigeria
}

\begin{abstract}
:
The global financial crisis that swept the financial markets and economies around the world, causing bankruptcies and resulting economic recession has brought the concept of corporate governance into the limelight. Hence this study examined the effect of corporate governance practices on sustainability of deposit money banks in Lagos Nigeria. The study adopted a quantitative methodology using the cross-sectional survey design. The population of the study comprised of fifteen selected deposit money banks operating in Nigeria as at March, 2019. Data was collected using a well-structured and validated research questionnaire with Cronbach's alpha ranging from 0.721 to 0.849. Data were analysed using multiple regression analysis. The study revealed that transparency and accountability jointly have a significant effect on business sustainability $\left(R^{2}=0.084, p=0.000<0.05\right)$. Hence, the study recommended that money deposit banks should adopt openness in their practices, they should be transparent in all they do at board level and should be committed to accountability at all levels of bank management in order to sustain customer's confidence.
\end{abstract}

Keywords: Accountability, business sustainability, corporate governance, money deposit bank, transparency

\section{Introduction}

Business sustainability has attracted different interest from researcher, industry players and regulators. Sharp practices, structures and documentations in business are areas of interest that affects the growth and sustainability of business organizations especially in the banking sector (Najera-Sanchez, 2020). The global financial crisis affected financial institutions and economies around the world bringing about economic recession and crisis that characterized financial markets world. In order to achieve sustainability, corporate governance culture is being adopted by organisation (Vidaver-Cohen, \& Bronn, 2015).

The Nigerian banking sector had witnessed a lot of distress, uncertainty and anxiety prior to the banking sector consolidation exercise that began in 2004. Investor's and depositor's funds were not guaranteed, eroding public confidence, with many of the banks becoming distressed due to capital inadequacy (Ikpefan \& Kazeem, 2013). The reforms introduced by the Central Bank of Nigeria, (CBN) the apex bank, saw about 89 banks reduced to 25 during the era of banking consolidation. These problems greatly impaired the quality of the bank's assets as non-performing assets became unbearable and became huge burdens on many of the banks. The financial intermediation role of the banks became heavily impaired while the macroeconomic activities seriously slowed down. It was against this background, that the CBN announced a major reform in the entire banking industry (Ojeaga, 2009).

The major challenges posed by the global financial melt-down to Nigeria according to Atuche (2009) and Egbulonu and Okonkwo (2015) include falling oil prices and dwindling government revenue which in turn affected the nation's external reserve. Consequently, the Naira has been under pressure and has lost more than 25 percent of its value since 2008 to date. More recently, declining capital inflow as a result of increased insecurity in Nigeria has added to the problem thereby discouraging foreign direct investment. This has the effect of worsening the problem of relatively high operating costs occasioned by decaying infrastructure like power, transportation and healthcare because of the dearth of funds for investment in infrastructural development (Soludo, 2009). The impact on banks is higher operational costs as well as loss of income that could have been earned from facilitating the inflow of capital into the economy. 
Scholars such as Agbanike, Nwani, Uwazie, Anochiwa, \& Enyoghasim, (2019); Akinlo \& Egbetunde, (2010); DavidWest, Aluko, \& Adetunji, (2019); Njoku \& Odii, (1991) have shown that deposit money banks in Nigeria are facing several challenges. The identified problems include low market share, reduced business, declining organizational survival, low firm size, low potentials for business sustainability and reduced capital. All these highlighted problems are attributed to poor corporate governance culture (Ogbonna \& Ogwo, 2013, Osuagwu, (2013). Thus, the issues of corporate scandals have forced the World to recognize and acknowledge the place of corporate governance practices on the global economy (Ofurum \& Torbira, 2011).

The objective of the study is therefore to examine the effect of corporate governance on sustainability in the banking industry in Nigeria.

\section{Literature Review}

\subsection{Corporate Governance}

According to Nguyen and Nguyen (2016) the definitions of corporate governance are divided into two types as either 'narrow' or 'broad'. The narrow set of definitions, which could be used in studies on corporate governance within a single country, concentrates on the internal mechanisms of corporate governance in ascertaining firm performance and maximizing shareholders' benefits. Corporate governance is defined as a set of systems, processes and principles which ensure that a company is governed in the best interest of all stakeholders (Pallavi, 2018). It ensures commitment to values and ethical conduct of business; transparency in business transactions; statutory and legal compliance; adequate disclosures and effective decision-making to achieve corporate objectives. In other words, corporate governance is about promoting corporate fairness, transparency and accountability. Good corporate governance is simply good business. Various scholars have measured corporate governance using different proxies such as institutional ownership, managerial ownership, board size, audit committee size, director's remuneration, board meeting, board independence, ownership structure, as well as board gender diversity (Irine \& Indah, 2016; Jegede, Akinlabi, \& Soyebo, 2013; Akpan \& Riman, 2012; Karam \& Sonia, 2015; Gadi, Emesuanwu, \& Shammah, 2015; Alexander, David, Musibau, \& Adunola, 2015; Joseph \& Ahmed, 2017).

In this case, the company is considered a social entity that has accountability and responsibility to a variety of stakeholders, encompassing shareholders, creditors, suppliers, customers, employees, management, government and the local community (Freeman \& Reed, 1983; West, 2006; Mallin, 2010). Rezaee (2009) describes corporate governance as an ongoing process of managing, controlling and assessing business affairs to create shareholder value and protect the interests of other stakeholders. According to this definition, there are seven important functions of corporate governance: oversight, managerial, compliance, internal audit, advisory, external audit and monitoring. These definitions support other schools that argue that a firm has an obligation not only to its shareholders, but to all stakeholders, whose contributions are necessary for the success of the firm (Donaldson \& Preston, 1995; Freeman, 1984). In these terms, Solomon (2010) defines corporate governance as 'the system of checks and balance, both internal and external to companies, which ensure that companies discharge their accountability to all their stakeholders and act in a socially responsible way in all areas of their business activity'.

Corporate governance is geared towards an efficient use of resources by reducing fraud and mismanagement with the view to balancing the interest of all stakeholder groups in a business entity. Mallin (2010), explains that the essential features of corporate governance are to assists in ensuring that an adequate and appropriate system of controls operates within a company and that assets may therefore be safeguarded; it avoids any single individual having too much influence; and it tries to encourage both transparency and accountability in the relationship between company management, the board of directors and other stakeholders, which investors are increasingly looking for in both corporate management and performance. In this study, corporate governance is measured using transparency and accountability as predictors of business sustainability.

\subsection{Transparency}

Transparency entails full disclosure of the financial information to reduce information asymmetry between the companies. The tenet of any corporate governance system is based on the goal of good financial reporting which complies with the complex accounting standards in conjunction with other regulatory requirements around the world (Fung, 2014). Ball (2009) view transparency as a public value embraced by society to counter corruption, transparency synonymous with open decision-making by governments and non-profits, and transparency as a complex tool of good governance in programs, policies, organizations, and nations (Ball, 2009). Transparent policies also provide information to citizens and improve their ability to make choices about the services they receive. A transparent policy is deemed effective when the public acts on the information the policy provides. Transparency is also open government and organizations (Piotrowski \& Watt, 2008).

\subsubsection{Accountability}

Kakumba \& Fourie (2007) defines accountability as the 'responsibility of government and its agents towards the public to achieve previously set objectives and to account for them in public'. Accountability is an assurance that an individual or an organization will be evaluated on their performance or behavior related to something for which they are responsible. Corporate accountability involves being answerable to all an organization's stakeholders for all actions and results. Hudaya (2011) explains that accountability involves explaining or justifying what has been done, what is currently being done and what has been planned. Accountability arises from a set of established procedures, and relationship of 
varying formality. Thus, one part is upon the other to give an account of his activities. Accountability therefore involves the giving of information. Mulgan (2000) defines accountability by saying that the core of accountability is the obligation to answer to a superior for one's actions and to accept appropriate remedies including sanctions. Mulgan (2000) defines accountability as a compulsory action to render an account of the conduct of the steward to the principal.

\subsubsection{Business Sustainability}

Business sustainability is defined as development that meets the needs of the present without compromising the ability of future generation to meet their own needs. Ford (2012) defined business sustainability as the ability to meet the needs of present customers while taking into account the needs of future generations. However, Epstein and Buhovac (2010) proffered that business sustainability is similar to oganizational sustainability as it enhances the ability of business organizations to better understand their host communities, customers, employees, stockholders and proffer solutions to their peculiar needs which may lead to better cooperation with the organization. For business, sustainability is about guaranteeing long-term business success while contributing towards economic and social growth, a healthy environment and a steady society (Epstein \& Buhovac, 2011). It is rapidly moving up the agenda as a prime business concern across the globe.

Business operations are at the heart of sustainability. According to Ogbo, Eneh, Agbaeze, Chukwu, and Isijola (2017), businesses practicing sustainability is important as it improves their image and reputation, reduce costs, and help boost the local economy, all of which leads to improved business, stronger and healthier local communities for operations. Hami, Mahamad and Ebrahim (2014) posit that, for any economy to survive for short term and long term purpose, then it must be able to meet the 'three bottom line' which has to do with the ability of the firms to achieve sustainability in environment, human and economic objectives of the firms.

Studies such as Chen, Feldmann and Tang, (2015); Schaltegger, (2011) and Sukitsch, Engert and Baumgartner (2015) claimed that business sustainability gives advantages and opportunities such as the potential for opening new markets, improving competitive position, generating greater consumer and shareholder acceptance, enhancing company image, improving employee motivation, and cost reduction. In the view of Setia and Soni (2013), business sustainability requires organizations to put into consideration long term economic, environmental, and social effects when formulating the production and other policies. Ekanem (2017) posited that organisations should implement effective sustainability practices, this can drive competitive advantage for an organization and power it towards a more innovative, sustainable and green future.

Business sustainability can be seen as an act that is concerned about the social, environmental, and economic impacts associated with its current and future operations and the ability of the business to meet present needs while ensuring its and others' long-term survival. Therefore, the focus of this study is the economic aspect of business sustainability. Doane and MacGilivray (2001) submitted that economic sustainability is the most elusive component of the triple bottom line approach which includes the economic, social and environmental sustainability. Economic sustainability refers to a business ability to make profit in order to survive and benefit the economic systems at the local and national level (Raderbauer, 2011; Roberts \& Tribe, 2008). Khan, Dewan and Chowdhurry (2014) concluded that economic sustainability consists of several aspects including employment, sales growth, income stability, profitability and return on investment. Economic sustainability has great implications for organisations, as submitted by Hami, Muhamad and Ebrahim (2015). Hence, business sustainability via the economic sustainability aspect is being seen in the study as competitive advantage, market share, sales growth, profitability and revenue growth.

\subsection{Corporate Governance and Business Sustainability}

Many of today's environment and social issues are in unsustainable pattern of economic and industrial development. Consequently driven by regulation and market factors and with the overall goal of building a competitive advantage, companies are developing new diversified corporate sustainability approaches (Hahn \& Sheermesser, 2006). In research business, business sustainability is defined in reference to the Tripple Bottom Line (TBL) as proposed by Ekington (1997) where the economic, social and environmental dimensions of business are simultaneously taken into account. There is evidence from literature that firms embed sustainability in their business models in different ways (Gupta \& Kumar, 2013); approach the TBL differently (Hahn \& Scheermesse, 2006) and develop short and long term initiatives measuring and reporting performance in different ways (Habib, 2016). In order to implement and control sustainability strategies and initiatives with the ultimate goal of improving sustainability performance, companies establish governance mechanisms and structures to manage relationships with the supply chain actors (Azutoru, Obinne \& Chinnelo, 2017). Furthermore literature have highlighted the role of collaborative approaches and different level of governance mechanism functions (Adetunji \& Olawoye, 2009; Azutoru, Obinne, \& Chinelo, 2017; Marn \& Romuald, 2012).

According to Lawrence, Collins and Roper (2013), corporate governance greatly influenced sustainability. The finding of Sar (2018) also reported that a good corporate governance has effect on sustainability. In the same vein, Mukherjee and Sen (2019) found a significant effect of corporate governance on corporate sustainability growth in India. Furthermore, Pintea and Fulop (2014) established that good corporate governance is important in achieving corporate sustainable growth. In view of the dearth of literature in Nigeria, the following hypothesis is tested:

- $\mathrm{H}_{01}$ : Corporate governance has no significant effect on sustainability.

\subsection{Stewardship Theory}

The stewardship theory was developed by Donaldson and Davis (1991). The main thrust of the theory is the understanding of the relationships between ownership and management of the company. It has been argued by 
McDonnell., Macknight, and Donnelly (2001), that stewardship theory also provides a good background for implementing corporate governance practices. In this theory, managers, as the controllers of an organisation, should act as stewards. Stewardship theory promotes partner-style working relationships between board members and the management team (McDonnell et al. 2001). It is the responsibility of the board members to add extra value to the organizational process by supporting management in their strategic decision-making. Kiragu, Aduda, and Ndwiga, (2013) state that being stewards, the directors and managers in business organizations must be trustworthy and so must show good stewardship of organizational resources. This theory states that superior corporate performance is highly dependent on the duties and functions of inside directors and corporate leaders (Kiragu et al. 2013). The decision-making process of senior managers should be governed so that they can fulfil all corporate governance obligations responsibly.

Stewardship theory suggests that managers in organizations have autonomy, through which the costs of monitoring can be minimized and the corporate behaviour of managers and directors can be properly controlled (Kiragu et al. 2013; Davis \& Cobb 1997). The theory assumes that the relationship between principal and the agents in based on choice (Madison, 2014) and the relationship is such that the agent behaves in a focused manner that directs trustworthy and moral behavior towards the organisation and its shareholders (Subramanian, 2018). The main challenge with stewardship theory is the issue of trust because critiquing the actions of management may not be done because of excessive trust (Grundei, 2008). However, the stewardship theory supports corporate governance and performance because it recognizes that there is a form of agency existing in a corporate setting and beliefs that directors are not concerned about themselves but about the interest of the organisation and will act in a way that the best interest of the organisation is achieved thereby fulfilling their personal needs (Keay, 2017).

\section{Methodology}

The study adopted a quantitative methodology using the cross-sectional survey design. Cross-sectional survey research design was adopted because the study has to do with a prevailing current trend in the society that concerns the operations of the economy. The population of the study comprised of fifteen (15) selected deposit money banks operating in Nigeria as at December, 2019. The condition for selecting them is that they have all been in existence for a continuous period of not less than 10 years, many of them having had their share of corporate governance challenges at different times and this had led to various forms of business combinations including regulatory induced takeovers, merger and acquisitions. On this note, total enumeration was adopted as the sampling technique. This allowed for selection of all elements of the study. Data for the study was collected using a well-structured and validated research questionnaire designed by the researchers. The Cronbach's alpha results range from 0.721 to 0.849 . The data gathered from the field of the study was edited to ensure that all questionnaires were completed and contained accurate information. Data collected was then analyzed using inferential statistics. The inferential statistics was used to test the hypothesis with a significance of 0.05. Multiple regression analysis was used specifically to test the influence of the independent variables on the criterion variable.

\section{Results and Discussions}

4.1. Multiple Regression Test to Evaluate the Effect of Transparency and Accountability on Business Sustainability of Selected Deposit Money Banks

\begin{tabular}{|c|c|c|c|c|c|c|}
\hline \multicolumn{2}{|r|}{ Model } & \multicolumn{2}{|c|}{ Unstandardized Coefficients } & \multirow{2}{*}{$\begin{array}{c}\begin{array}{c}\text { Standardized } \\
\text { Coefficients }\end{array} \\
\text { Beta } \\
\end{array}$} & \multirow[t]{2}{*}{$\mathbf{T}$} & \multirow[t]{2}{*}{ Sig. } \\
\hline & & $\mathrm{B}$ & Std. Error & & & \\
\hline \multirow[t]{3}{*}{1} & (Constant) & 13.317 & 1.927 & & 6.911 & 0.000 \\
\hline & Transparency & 0.218 & 0.062 & 0.299 & 3.520 & 0.001 \\
\hline & Accountability & -0.262 & 0.148 & -0.150 & $\begin{array}{l}-1.768 \\
\end{array}$ & 0.079 \\
\hline
\end{tabular}

Source: Field Survey Results, 2020

Dependent Variable: Business Sustainability

$R=0.289, R^{2}=0.084, F=14.672$

The table above presents the result of the multiple regression analysis to test the effect of transparency and accountability on the sustainability of selected deposit money banks in Lagos State, Nigeria. The variables used as independents are transparency and accountability while business sustainability was used as the dependent variable in the study. According to the multiple regression results presented in the Table above, value of coefficient of determination of dimensions of corporate of listed banks in the study which $\left(\mathrm{R}^{2}\right)$ was 0.084 , whilst this result implies that $8.4 \%$ of total variance in business sustainability can be explained by all dimensions of corporate governance (transparency and accountability). As the model reveals the remaining $91.6 \%$ of variability was not explained in this model. Thus, any improvement in corporate governance component as, transparency and accountability, causes a combined effect of $8.4 \%$ on business sustainability of the selected deposit money banks. An analysis indicates that $F=2.32$, p $<0.05$ that model was significant. 


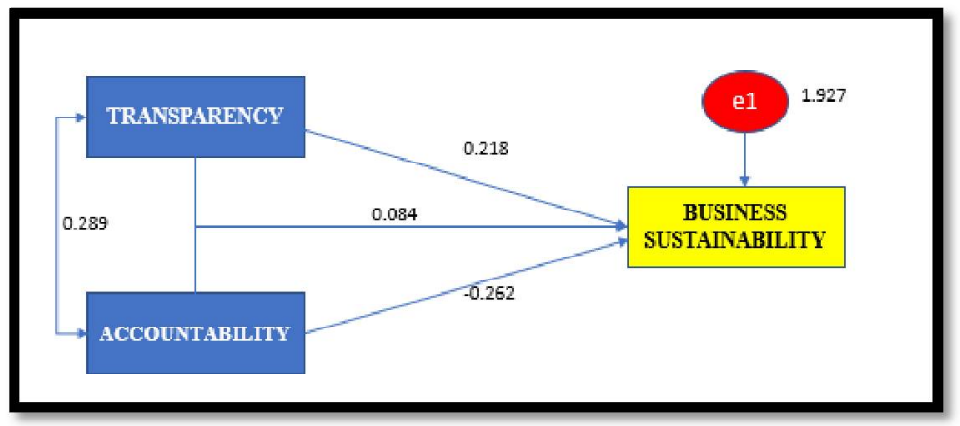

Figure 1

The individual effects of transparency and accountability on business sustainability is evaluated by looking at the unstandardized coefficients. It is seen that transparency has a coefficient of 0.218 which suggest that a unit change in transparency would have a concomitant 0.218 change in sustainability and this result is statistically significant given a probability value of 0.001 . Further analysis shows that accountability has a coefficient of -0.262 and it statistically insignificant given a probability value of 0.079 . According to the results of the study hypothesis was rejected that corporate governance has no significant effect on sustainability. The results revealed that $8.4 \%$ variability on business sustainability has been explained by independent variables.

\section{Discussion}

Different studies have been done in the area of transparency and accountability as factors to enhance business sustainability. Although in this study it was found that accountability has no significant effect on business sustainability while transparency has a significant effect on sustainability. In line with this, Doane and MacGilivray (2001) submits that economic sustainability is the most elusive component of the triple bottom line approach which includes the economic, social and environmental sustainability. Khan, Dewan and Chowdhurry (2014) on their own part concluded that economic sustainability consists of several aspects including employment, sales growth, income stability, profitability and return on investment which is influenced by good corporate governance structure. In the same vein, the studies of Hami, Muhamad and Ebrahim (2015); Lawrence, Collins and Roper (2013); Sar (2018); Mukherjee and Sen (2019) and Pintea and Fulop (2014) confirmed that corporate governance dimensions have positive effect on sustainability. The finding that accountability does not have a significant effect on business sustainability negates the findings of other studies. This can be attributed to contextual differences, discrepancies in data collection of differences in designs of these studies.

\section{Conclusions and Recommendations}

This study concluded that corporate governance has a significant effect on business sustainability. Based on this, it is recommended that organizations especially in banking sector should adopt openness in their practices, they should be transparent in all that they do at board level. Issues bothering on Accountability should be improved in order to restore customers confidence in the banking system. The principles of the stewardship theory should be applied where managers, as the controllers of an organisation, should act as stewards. Stewardship theory promotes partner-style working relationships between board members and the management team. This will ensure greater transparency and accountability of the deposit money banks.

\section{References}

i. Adetunji, B.M. \& Olawoye, O. (2009): The Effect of Internal and External Mechanism on Governance and Performance of Corporate Firms in Nigeria. Corporate Ownership and Control, 7(2-3), 230-242.

ii. Agbanike, T. F., Nwani, C., Uwazie, U. I., Anochiwa, L. I., \& Enyoghasim, M. O. (2019). Banking sector development and energy consumption in Nigeria: exploring the causal relationship and its implications. African Development Review, 31(3), 292-306.

iii. Akinlo, A. E., \& Egbetunde, T. (2010). Financial development and economic growth: The experience of 10 subSaharan African countries revisited. The Review of Finance and Banking, 2(1), 017-028.

iv. Akpan, E., \& Roman, H. B. (2012). Does corporate governance affect bank profitability? Evidence from Nigeria. American International Journal of Contemporary Research, 2, 135-145.

v. Alexander, O. B., David, T. I., Musibau, A. A., \& Adunola, O. O. (2015). Impact of Corporate Governance on Firms' Performance. International Journal of Economics, Commerce and Management, 3(6), 635-653.

vi. Atuche F. (2009). Nigerian banking system and the challenges of the global economic crisis. Central Bank of Nigeria Bullion, July-September edition.

vii. Azutoru, I. H. C., Obinne, U. G., \& Chinelo, O. 0. (2017). Effect of corporate governance mechanisms on financial performance of Insurance Companies in Nigeria. Journal of Finance and Accounting, 5(3), 93-103.

viii. Ball, C. (2009). What Is Transparency? Public Integrity, 11(4) 293-308.

ix. Cadbury, S.A. (1999) Sir, what are the trends in corporate governance? How will they impact your company? Long Range Planning, 32, 12-19.

x. Chen, L., Feldmann, A., \& Tang, O. (2015). The relationship between disclosures of corporate social performance and financial performance: Evidence from GRI reports in manufacturing industry. International Journal of Production Economics, 170, 445-456 
xi. David-West, O., Aluko, T., \& Adetunji, O. (2019). Mobile money: A panacea for financial exclusion in emerging markets. Journal of Banking, 8(1), 27-55.

xii. Davis, G. F., \& Cobb J. A. (1997). Resource dependence theory: Past and future. Stanford's organization theory renaissance, 1970-2000. Bingley, NY: Emerald Group.

xiii. Doane, D. \& MacGilivray, A. (2001). Economic sustainability: The business of staying in business, The Sigma Project March 2001. Retrieved from

https://pdfs.semanticscholar.org/2a4e/da2c8660dc0d02a514512d96bd1bc1d4808a.pdf on December 15, 2019

xiv. Donaldson, O., \& Davis, J.H. (1991). Stewardship theory or agency theory: CEO governance and shareholder returns. New York: Lex Donaldson.

xv. Donaldson, T., \& Preston, L. (1995). The stakeholder theory of the modern corporation: concepts, evidence and implications. Academy of Management Review, 20, 65-91.

xvi. Egbulomu, K. G., \& Okonkwo, O. N. (2015). A critical review of the effect of the global financial melt-down on the Nigerian banking section. Research on Humanities and Social Sciences, 5(2), 109-116.

xvii. Ekanem, I. S. (2017). Intellectual capital and organizational sustainability in manufacturing firms in Rivers State. International Journal of Advanced Academic Research, 3(4), 1-17.

xviii. $\quad$ Elkington, J. (1997). Cannibals with Forks: The Triple Bottom Line of 21st Century Business. Capstone: Oxford.

xix. Epstein, M. J., \& Buhovac, A. R. (2010). Solving sustainability implementation challenges. Organizational Dynamics, 39, 306-315.

xx. Ford, 0. (2012). http://corporate.ford.com/doc/corpgov_sustainability_committee.pdf. Retrieved December 12, 2019.

xxi. Freeman, R. E. (1984). Strategic management: A stakeholder approach. Boston: Pitman.

xxii. Freeman, R. E., \& Reed, D. (1983). Stockholders and Stakeholders: A New Perspective on Corporate Governance. California Management Review, 25(3), 88-106.

xxiii. Fung, B. (2014). The Demand and Need for Transparency and Disclosure in Corporate Governance. Universal Journal of Management, 2(2), 72-80.

xxiv. Gadi, P., Emesuanwu, E., \& Shammah, Y. (2015). Impact of corporate governance on financial performance of microfinance banks in north central Nigeria. International Journal of Humanities Social Sciences and Education (IJHSSE), 2(1), 153-170.

xxv. Gupta, S., \& Kumar, V. (2013). Sustainability as corporate culture of a brand for superior performance. Journal of World Business, 48(2), 311-320.

xxvi. Grundei, J. (2008). Are managers agents or stewards of their principals? Logic, critique, and reconciliation of two conflicting theories of corporate governance. J Betriebswirtsch, 58, 141-166.

xxvii. Habib, M. A. (2016). Relationship between corporate governance and firm performance: a case study in Bangladesh. International Scholar Journal of Accounting and Finance, 2(1), 11-20.

xxviii. Hahn, T., \& Scheermesser, M. (2006). Approaches to corporate sustainability among German companies. Corporate Social Responsibility and Environmental Management 13(3), 150 - 165.

xxix. Hami, N., Muhamad, M. R. \& Ebrahim, Z. (2015). The impact of sustainable manufacturing practices and innovation. Procedia CIRP, 26, 190 - 195.

xxx. Hudaya, M. (2014). Understanding the practice of accountability reporting: A case of Indonesian local government, PhD Thesis, University of Wollongong.

xxxi. Ikpefan, O. A., \& Kazeem, B. L. O. (2013). The effect of merger on deposit money banks' performance in the Nigerian banking industry. European Journal of Accounting Auditing and Finance Research, 2(1), 32-49.

xxxii. Irine, H., \& Indah, S. (2017). The Effect of Corporate Governance on the Performance of a Company. Some Empirical Findings from Indonesia. Journal of Management and Business Administration, Central Europe, 25, 33-52.

xxxiii. Jegede, C. A., Akinlabi, B. H., \& Soyebo, Y. A. (2013). Corporate Governance Efficiency and Bank Performance in Nigeria. World Journal of Social Sciences, 3(1), 178 - 192.

xxxiv. Joseph, B. A., \& Ahmed, A. B. (2017) Corporate governance and financial reporting quality in Nigeria. International Journal of Information Research and Review, 4(2), 3749-3753.

xxxv. Kakumba, U., \& Fourie, D. J. (2007). Revitalising accountability in public management reform: Issues and challenges for developing countries. Journal of Public Administration, 42(7), 650-663.

xxxvi. Karam P. N., \& Sonia J. (2015). The impact of corporate governance on the profitability: An empirical study of Indian textile industry. International Journal of Research in Management, Science \& Technology 3(2), 43-59.

xxxvii. Keay, A. (2017). Stewardship theory: Is board accountability necessary? International Journal of Law and Management, 59(6), 1292-1314.

xxxviii. Khan, E. A., Dewan, M. N. A., \& Chowdhury, M. M. H. (2013). Development and validation of a Scale for measuring sustainability construct of informal microenterprises Retrieved from http://wbiworldconpro.com.

xxxix. Kiragu, P., Aduda, J. O., \& Ndwiga, J. M. (2013). The relationship between agency banking and financial performance of commercial banks in Kenya. Journal of Finance and Investment Analysis, 2(4), 97-117.

xl. Lawrence, S., Collins, E., \& Roper, J. (2013). Expanding responsibilities of corporate governance: The incorporation of CSR and sustainability. Indian Journal of Corporate Governance, 6(1), 49-63.

xli. Madison, K. J. (2014). Agency theory and stewardship theory integrated, expanded and bounded by context: An empirical investigation of structure, behaviour and performance within family firms. A PhD Dissertation, The University of Tennessee.

xlii. Mallin, C. A. (2010). Corporate Governance, Oxford: Oxford University Press. 
xliii. Mulgan, R. (2000). 'Accountability' An ever-expanding concept. Public Administration, 78, 555-574.

xliv. McDonnell, D., Macknight, E., \& Donnelly, H. (2001). Democratic Enterprise: Ethical business for the 21st century. Diarmuid McDonnell.

xlv. Mukherjee, T., \& Sen, S. S. (2019). Impact of corporate governance on corporate sustainable growth. International Research Journal of Business, 12(2), 167-183.

xlvi. Mulgan, R. (2000). Comparing accountability in the public and private sectors. Australian Journal of Public Administration, 59(1), 8797.

xlvii. Najera-Samchez, J. J. (2020). A systemic review of sustainable banking through a co-word analysis. Sustainability, 12-278, 1-23.

xlviii. $\quad$ Nguyen, V., \& Nguyen, A. (2016). Corporate governance structures and performance of firms in Asian markets: A comparative analysis between Singapore and Vietnam. Organizations and markets in emerging economies. [ejournal], 7(2), 112-140.

xlix. Njoku, J. E., \& Odii, M. A. C. A. (1991). Determinants of loan repayment under the special emergency loan scheme in Nigeria: a case study of Imo State. African Review of Money Finance and Banking, 1, 39-52.

l. Ofurum, C. O., \& Torbira, L. L. (2011). Corporate governance and firm performance in Nigeria. International Journal of Engineering and Management Research, 1(4), 1 - 11.

li. Ogbo, A. I., Eneh, N. C. J., Agbaeze E. K., Chukwu, B. I., \& Isijola, D. O. (2017). Strategies for achieving sustainable economy in Nigeria taking into consideration the acceptable stakeholders. African Journal of Business Management, 11(19), 582-589.

lii. Ogbonna, B. U., \& Ogwo, E. O. (2013). Market orientation and corporate performance of Insurance Firms in Nigeria. International Journal of Marketing Studies; 5(3), 104-116.

liii. Ojeaga, P. J. (2009). The impact of the global financial crisis on the Nigerian Banking Industry. MBA Thesis, Department of economics, SLU, Uppsala.

liv. Osuagwu, G. O. (2013). Implications of corporate governance on the performance of deposit money banks in Nigeria (2005 - 2010). Arabian Journal of Business and Management Review, 2(10), 107-119.

lv. Pallavi, V. (2018). Corporate governance: a literature review with a focus on public sector undertakings in India. People. International Journal of Social Sciences, 4(1), 17-32.

lvi. Pintea, M-O., \& Fülöp, M. T. (2014). Corporate governance and performance in the context of sustainable development. SEA: Practical Application of Science, 2(3), 519-525.

lvii. Raderbauer, M. (2011). Strategic Sustainability-Strategic implementation of Sustainable Business practice in Viennese Accommodation. Master thesis, University of Exeter, Devon, UK.

lviii. Rezaee, Z. (2009). Corporate Governance and Ethics. John Wiley \& Sons, Inc, USA.

lix. Roberts, S., \& Tribe, J. (2008). Sustainability indicators for small tourism enterprises - an exploratory perspective. Journal of Sustainable Tourism, 16(5), 575-594.

lx. Sar, A. K. (2018). Impact of corporate governance on sustainability: A study of the Indian FMCG industry. Academy of Strategic Management Journal, 17(1), 1-10.

lxi. Schaltegger, S. (2011). Sustainability as a driver for corporate economic success: Consequences for the development of sustainability management, control. Society and Economy, 33(1), 15-28.

lxii. Solomon, J. (2010). Corporate governance and accountability. (3rd edition). West Sussex: John Wiley and Son Limited.

lxiii. Soludo, C. C. (2009). Global financial and economic crisis, how vulnerable is Nigeria?, Presentation by Professor C. C. Soludo, Governor of CBN to The House Of Representative Committee on Bank Currency on Jan. 21, 2009. Retrieved on April, 20, 2019 from www. Cenbank.org/out/speeches/2009/gov.

lxiv. Setia, S., \& Soni, M. (2013). Sustainability in manufacturing. The Technology Landscape White Paper Manufacturing.

lxv. Subramanian, S. (2018). Stewardship theory of corporate governance and value system: The case of family-owned business group in India. Indian Journal of Corporate Governance, 11(1), 88-102.

lxvi. Suckitsch, M., Engert, S., \& Baunmgartner, R. J. (2015). The implementation of corporate sustainability in the European automotive industry: An analysis of sustainability reports. Sustainability, 7(9), 11504-11531.

lxvii. Vidaver-Cohen, D., \& Bronn, P. (2015). Reputation, responsibility, and stakeholder support in Scandinavian firms: A comparative analysis. Journal of Business Ethics, 127(1), 49-64.

lxviii. West, R. (2006). The Transtheoretical model of behaviour change and the scientific method. Addiction, 101(6), 116 